\title{
Correction to: Elevated Allochthony in Stream Food Webs as a Result of Longitudinal Cumulative Effects of Forest Management
}

\author{
Maitane Erdozain, ${ }^{1 *} \odot$ Karen A. Kidd, ${ }^{2} \odot$ Erik J. S. Emilson, ${ }^{3} \odot$ \\ Scott S. Capell, ${ }^{3}$ David P. Kreutzweiser, ${ }^{3}$ and Michelle A. Gray ${ }^{4}$
}

\begin{abstract}
${ }^{1}$ Canadian Rivers Institute and Biology Department, University of New Brunswick, 100 Tucker Park Road, Saint John, New Brunswick E2L 4L5, Canada; ${ }^{2}$ Department of Biology and School of Earth, Environment and Society, McMaster University, 1280 Main St. W., Hamilton, Ontario L8S 4K1, Canada; ${ }^{3}$ Great Lakes Forestry Centre, Natural Resources Canada, Canadian Forest Service, 1219 Queen St. East, Sault Ste. Marie, Ontario P6A 2E5, Canada; ${ }^{4}$ Canadian Rivers Institute and Faculty of Forestry and Environmental Management, University of New Brunswick, 28 Dineen Drive, Fredericton, New Brunswick E3B 5A3, Canada
\end{abstract}

\section{Correction to: ECOSYSTEMS}

HTTPS://DOI.ORG/10.1007/s10021-021-00717-6

This paper has been re-published with open access.

\section{OPEN ACCESS}

This article is licensed under a Creative Commons Attribution 4.0 International License, which permits use, sharing, adaptation, distribution and reproduction in any medium or format, as long as you give appropriate credit to the original author(s) and the source, provide a link to the Creative
Commons licence, and indicate if changes were made. The images or other third party material in this article are included in the article's Creative Commons licence, unless indicated otherwise in a credit line to the material. If material is not included in the article's Creative Commons licence and your intended use is not permitted by statutory regulation or exceeds the permitted use, you will need to obtain permission directly from the copyright holder. To view a copy of this licence, visit $h$ ttp://creativecommons.org/licenses/by/4.0/.

Published online 22 February 2022

The original article can be found online at https://doi.org/10.1007/s100 21-021-00717-6.

*Corresponding author; e-mail: maitane.erdozain@gmail.com 